\title{
KARAKTERISTIK IBU HAMIL DAN KAITANNYA DENGAN KEJADIAN STUNTING PADA BALITA DI KECAMATAN TAMANSARI KOTA TASIKMALAYA
}

\section{CHARACTERISTICS OF PREGNANT WOMAN WITH STUNTING AMONG TODDLER IN TAMANSARI SUB-DISTRICT TASIKMALAYA CITY}

\author{
Irma Nuraeni ${ }^{1^{*}}$, Helmi Diana ${ }^{2}$ \\ 1,2Poltekkes Kemenkes Tasikmalaya, Indonesia \\ email: ${ }^{*}$ irma_nuraeni20@yahoo.com, ${ }^{2}$ ibundaaby@gmail.com
}

\begin{abstract}
ABSTRAK
Stunting pada balita merupakan salah satu permasalahan kesehatan pada balita di Indonesia diantara masalah lainnya. Prevalensi stunting menurut data Riset Kesehatan Dasar 2013 termasuk kategori tinggi yaitu sebesar $37.2 \%$. Tujuan penelitian untuk mengetahui karakteristik ibu hamil dan kaitannya dengan kejadian stunting pada balita di Kelurahan Mulyasari Kecamatan Tamansari Kota Tasikmalaya. Jenis penelitian observasional dengan desain casecontrol pada 105 pasangan ibu-balita stunting dan 105 non-stunting. Variabel karakteristik lbu hamil diantaranya adalah: usia ibu pada saat hamil, umur kehamilan, jarak kelahiran, dan tinggi badan ibu. Data dianalisis secara statistik menggunakan chi square dan regresi logistik sederhana. Hasil penelitian menunjukkan tidak ada perbedaan yang signifikan variabel usia ibu pada saat hamil, umur kehamilan, dan jarak kelahiran antara balita stunting dan non-stunting, sedangkan tinggi badan ibu secara signifikan merupakan faktor risiko stunting pada balita usia $0-59$ bulan $(p$ value $=0,000 ; \alpha<0,05)$. Simpulan diketahui tinggi badan ibu $<145 \mathrm{~cm}$ berisiko terjadinya stunting pada balita sebesar 5,712 kali dibandingkan dengan ibu dengan tinggi badan $\geq 145 \mathrm{~cm}$. Perlu adanya upaya pencegahan peningkatan faktor risiko lainnya terhadap stunting disamping maternal faktor.
\end{abstract}

Kata Kunci : Karakteristik Ibu Hamil, Stunting, Balita, Tinggi Badan

\begin{abstract}
Stunting among toddlers is one of the health problem health in Indonesia. The prevalence of stunting according to Health Research of Ministry of Health Data 2013, the prevalance was high $37.2 \%$. The purpose of this study was to determine the characteristics of pregnant woman associated with stunting among toddlers in Mulyasari Urban Village, Tamansari sub-district, Tasikmalaya City. The type of this study was observational with case-control design on mother and toddler mates 105 stunting and 105 non-stunting. Variable of characteristics is maternal age, gestational age, birth spacing and height of mother. Data were analyzed statistically using chi square test. The results showed there was no statistically significant differences in maternal age variables during pregnancy, gestational age, and birth spacing between toddlers stunting and non-stunting, while maternal height was significantly a risk factor for stunting in toddlers aged $0-59$ months ( $p$ value $=0,000 ; \alpha<0,05$ ). The conclusion is toddlers with height of mother $<145 \mathrm{~cm}$ risk stunting equal to 5,712 compared with toddler with mother height $\geq 145 \mathrm{~cm}$. Recommendation of this research is to prevent an increasing another risk factors for stunting beside maternal factor.
\end{abstract}

Keywords: Characteristics of Pregnant Woman, Stunting, Toddler, Height 


\section{PENDAHULUAN}

Stunting (pendek) menurut data Riskesdas tahun 2013 menunjukkan prevalensi $37.2 \%$, yang terdiri dari $18,0 \%$ sangat pendek dan 19,2 \% pendek ${ }^{1}$. Berdasarkan prevalensi tersebut, kejadian stunting menjadi masalah karena besarnya prevalensi berada di atas toleransi yang ditetapkan. Berdasarkan data yang diperoleh dari UPTD Puskesmas Tamansari Bulan Penimbangan Balita (BPB) Februari tahun 2015 dan 2016, Kelurahan Mulyasari merupakan kelurahan dengan jumlah terbanyak adanya balita pendek dan sangat pendek jika dibandingkan dengan kelurahan lainnya. Diantaranya terdapat 24 balita sangat pendek dan 39 balita pendek pada Februari 2015, sedangkan pada Februari 2016 terdapat sejumlah 11 balita sangat pendek dan 37 balita pendek, dengan prevalensi stunting $4,5 \%{ }^{2}$.

Stunting pada balita, dipengaruhi oleh masa pertumbuhannya. Masa dua tahun pertama kehidupan merupakan periode Window of Opportunity, yang merupakan kesempatan singkat untuk melakukan hal yang bermanfaat bagi tumbuh kembang anak. Apabila pada periode ini kesempatan tersebut terlewatkan, maka berbagai macam risiko untuk terjadinya penyakit, mudah sakit, perkembangan lambat, dan perkembangan kognitif yang terganggu, sehingga dikhawatirkan terjadi penurunan produktivitas $^{3}$.

Masalah kekurangan gizi balita termasuk stunting yang berkaitan dengan faktor ibu, seperti keadaan gizi ibu pada saat remaja dan hamil serta praktek pemberian makan bayi oleh $\mathrm{Ibu}^{4}$. Penelitian menunjukkan pendidikan Ibu, kehamilan terlalu dini, jumlah anggota rumah tangga dan orang tua pendek sangat berkaitan dengan kejadian stunting ${ }^{5,6,7,8}$.

\section{METODE}

Penelitian ini sudah mendapat persetujuan etik penelitian kesehatan dari
Komisi Etik Peneltian Kesehatan (KEPK) Politeknik Kesehatan Kemenkes Bandung No. 25/KEPK/PE/X/2016

Jenis Penelitian observasional dengan desain case-control, untuk mengetahui karakteristik Ibu hamil seperti, usia ibu, tinggi badan ibu, umur kehamilan dan jarak kelahiran terhadap kejadian stunting pada balitadi Kelurahan Mulyasari Kecamatan Tamansari Kota Tasikmalaya. Penelitian ini dilaksanakan pada bulan Oktober-November 2016 di Kelurahan Mulyasari, Kecamatan Tamansari, Kota Tasikmalaya.

Sampel penelitian adalah pasangan ibu dan balita 105 stunting dan 105 non-stunting, yang dipilih menggunakan teknik purposive sampling. Pengumpulan data primer berupa status gizi dengan mengukur secara langsung antropometri panjang badan/tinggi badan oleh peneliti bersama tenaga terlatih/enumerator menggunakan length board. Pengumpulan data sekunder berupa usia ibu pada saat hamil, tinggi badan ibu, umur kehamilan dan jarak kelahiran diambil dari KIA disertai validasi menggunakan formulir/kuesioner kepada ibu responden dengan cara wawancara oleh enumerator dan peneliti.

Analisis univariat digunakan untuk melihat distribusi frekuensi karakteristik subjek penelitian yaitu usia ibu pada saat haml, tinggi badan ibu, umur kehamilan dan jarak kelahiran. Sedangkan analisis bivariat digunakan untuk melihat apakah terdapat perbedaan karakteristik antara variabel usia ibu, tinggi badan ibu, umur kehamilan dan jarak kelahiran dengan status gizi dalam hal ini adalah stunting (kasus) dan non stunting (control) menggunakan chi square test.

\section{HASIL}

Hasil penelitian pada Tabel 1 menunjukkan gambaran karakteristik ibu dan balita stunting dan non stunting di Kelurahan Mulyasari Kota Tasikmalaya. Karakteristik ibu dan balita yang dikaji tersebut adalah usia anak, jenis kelamin, asal posyandu, usia ibu pada saat hamil, umur kehamilan, jarak kehamilan dan tinggi badan ibu. 
Jumlah balita yang berjenis kelamin perempuan pada penelitian ini lebih banyak dibandingkan dengan laki-laki. Kelompok dari posyandu-posyandu di Kelurahan Mulyasari, dengan jumlah sampel terbanyak pada stunting di Cicantel 2, Ciburuyan 1, Tanjungsari dan Mulyasari. Sebagian besar ibu pada saat hamil pada penelitian ini adalah pada usia lebih dari 20 tahun, tinggi badan ibu pada saat hamil lebih dari $145 \mathrm{~cm}$, umur kehamilan lebih dari 37 minggu.

Tabel 1. Karakteristik Ibu dan Anak Stunting dan Non-Stunting di Kelurahan Mulyasari Kecamatan Tamansari Kota Tasikmalaya

\begin{tabular}{|c|c|}
\hline Karakteristik & $\begin{array}{c}\text { Proporsi Total } \\
\text { N (\%) }\end{array}$ \\
\hline $\begin{array}{c}\text { Kelompok usia Anak } \\
0 \text { - } 12 \text { bulan } \\
12 \text { - } 24 \text { bulan } \\
25 \text { - } 36 \text { bulan } \\
37 \text { - } 48 \text { bulan } \\
49 \text { - } 59 \text { bulan }\end{array}$ & $\begin{array}{l}11(5,2) \\
46(21,9) \\
64(30,5) \\
50(23,8) \\
39(18,6)\end{array}$ \\
\hline $\begin{array}{l}\text { Jenis kelamin } \\
\text { Laki-laki } \\
\text { Perempuan } \\
\end{array}$ & $\begin{array}{l}116(55,2) \\
94(44,8) \\
\end{array}$ \\
\hline $\begin{array}{l}\text { Posyandu } \\
\text { Ciburuyan } 1 \\
\text { Cicantel } 1 \\
\text { Cicantel } 2 \\
\text { Gunung Kanyere } 1 \\
\text { Komplek LIK } \\
\text { Mulyasari } \\
\text { Perum MB } \\
\text { Sumur Dago } \\
\text { Tanjungsari }\end{array}$ & $\begin{array}{l}37(17,6) \\
13(6,2) \\
57(27,1) \\
20(9,5) \\
13(6,2) \\
29(13,8) \\
2(1,0) \\
4(1,9) \\
35(16,7)\end{array}$ \\
\hline $\begin{array}{l}\text { Usia Ibu pada saat } \\
\text { hamil } \\
\quad<20 \text { tahun } \\
\quad \geq 20 \text { tahun }\end{array}$ & $\begin{array}{c}12(5,7) \\
198(94,3)\end{array}$ \\
\hline $\begin{array}{l}\text { Tinggi Badan lbu } \\
\quad<145 \mathrm{~cm} \\
\quad \geq 145 \mathrm{~cm}\end{array}$ & $\begin{array}{c}33(15,7) \\
177(84,3)\end{array}$ \\
\hline $\begin{array}{c}\text { Umur Kehamilan } \\
\leq 37 \text { minggu } \\
>37 \text { minggu }\end{array}$ & $\begin{array}{c}46(21,9) \\
164(78,1) \\
\end{array}$ \\
\hline $\begin{array}{l}\text { Jarak Kelahiran } \\
\text { Tidak ada } \\
\text { Dekat }<1 \text { Tahun } \\
\text { Jauh } \geq 1 \text { Tahun }\end{array}$ & $\begin{array}{c}69(32,9) \\
3(1,4) \\
138(65,7)\end{array}$ \\
\hline
\end{tabular}

anak balita usia 25-36 bulan baik pada stunting maupun non-stunting merupakan proporsi paling banyak. Responden diperoleh

Hasil pengukuran tinggi badan balita terdapat perbedaan rata-rata antara stunting dan nonstunting, yang mana pada balita stunting memiliki nilai lebih besar. Variabel tinggi badan ibu menunjukkan bahwa adanya perbedaan rerata yang cukup besar, pada lbu dengan balita stunting tinggi badannya dibawah $150 \mathrm{~cm}$, sedangkan lbu dengan balita non-stunting, rerata tinggi badannya mencapai lebih dari $150 \mathrm{~cm}$.

Rerata usia ibu pada saat hamil lebih tinggi pada yang stunting dibandingkan dengan pada balita non stunting.

Tabel 2. Rerata Variabel lbu dan Anak Stunting dan Non Stunting di Kelurahan Mulyasari Kecamatan Tamansari Kota Tasikmalaya

\begin{tabular}{lcc}
\hline \multicolumn{1}{c}{ Variabel } & $\begin{array}{c}\text { Stunting } \\
\text { (Rerata } \pm S D)\end{array}$ & $\begin{array}{c}\text { Non } \\
\text { Stunting } \\
\text { (Rerata } \pm S D)\end{array}$ \\
\hline $\begin{array}{l}\text { Tinggi Badan / } \\
\text { Panjang Badan }\end{array}$ & $83,17 \pm 10,80$ & $88,06 \pm 14,18$ \\
Anak (cm) & & \\
\hline $\begin{array}{l}\text { Usia lbu pada } \\
\text { saat hamil (tahun) }\end{array}$ & $29,10 \pm 6,55$ & $28,78 \pm 5,58$ \\
\hline $\begin{array}{l}\text { Tinggi Badan lbu } \\
\text { (cm) }\end{array}$ & $148,19 \pm 4,59$ & $151,54 \pm 4,59$ \\
\hline
\end{tabular}

Hasil analisis statistik pada penelitian ini ditujukan di Tabel 3, yaitu tidak adanya perbedaan yang signifikan pada variabel usia ibu pada saat hamil, umur kehamilan dan jarak kelahiran antara balita stunting dengan non stunting (nilai $p$-value $>0,05$ ). Variabel tinggi badan ibu menunjukkan adanya perbedaan yang signifikan $(p<0,05)$ antara kasus, yaitu balita stunting dengan non stunting, dengan nilai Crude Odds Ratio sebesar 5,712, sehingga tinggi badan merupakan faktor risiko terhadap kejadian stunting. Artinya, tinggi badan ibu pada saat hamil $<145 \mathrm{~cm}$ berisiko terjadinya stunting pada balita sebesar 5,712 kali dibandingkan dengan ibu yang memiliki tinggi badan $\geq 145$ $\mathrm{cm}$. 
Tabel 3. Nilai Crude Odds Rasio (COR) dan Interval Konfidensi 95 Karakteristik Ibu Hamil di Kelurahan Mulyasari Kecamatan Tamansari Kota Tasikmalaya

\begin{tabular}{|c|c|c|c|c|c|c|}
\hline \multirow{3}{*}{$\begin{array}{c}\text { Variabel } \\
\text { Status Karakteristik Ibu } \\
\text { Hamil }\end{array}$} & \multicolumn{4}{|c|}{ Stunting } & \multirow[t]{3}{*}{ COR } & \multirow[t]{3}{*}{$\mathrm{p}$-value } \\
\hline & \multicolumn{2}{|c|}{$\mathrm{Ya}$} & \multicolumn{2}{|c|}{ Tidak } & & \\
\hline & $\mathrm{n}$ & $\%$ & $\mathrm{~N}$ & $\%$ & & \\
\hline \multicolumn{7}{|l|}{ Usia Ibu pada saat hamil } \\
\hline$<20$ tahun & 8 & 66,7 & 4 & 33,3 & 2,08 & 0,234 \\
\hline$\geq 20$ tahun & 97 & 48,9 & 101 & 51,0 & 1.00 & (ref) \\
\hline \multicolumn{7}{|l|}{ Tinggi Badan Ibu } \\
\hline$<145 \mathrm{~cm}$ & 27 & 81,8 & 6 & 18,2 & 5,71 & 0.000 \\
\hline$\geq 145 \mathrm{~cm}$ & 78 & 44,1 & 99 & 55,9 & 1.00 & (ref) \\
\hline \multicolumn{7}{|l|}{ Umur Kehamilan } \\
\hline$\leq 37$ minggu & 27 & 58,7 & 19 & 41,3 & 1,56 & 0,182 \\
\hline > 37 minggu & 78 & 47,6 & 86 & 52,4 & 1.00 & (ref) \\
\hline \multicolumn{7}{|l|}{ Jarak Kelahiran } \\
\hline Dekat $<1$ tahun & 2 & 66,7 & 1 & 33,3 & 0,49 & 1,000 \\
\hline Tdk ada+Jauh $\geq 1$ Tahun & 103 & 49,8 & 104 & 50,2 & 1,00 & (ref) \\
\hline
\end{tabular}

\section{PEMBAHASAN}

Penyebab stunting sangat beragam dan kompleks. Penelitian ini melihat penyebab stunting dari faktor yang mendasari (underlying factors), yang berhubungan dengan faktor keluarga yaitu status karakteristik ibu pada saat hamil, karena masalah kekurangan gizi balita termasuk didalamnya adalah stunting berkaitan dengan faktor ibu, seperti keadaan gizi ibu pada saat remaja dan hamil ${ }^{4}$.

Hasil analisis bivariat menunjukkan tidak ada perbedaan yang signifikan pada variabel usia ibu pada saat hamil, umur kehamilan, dan jarak kelahiran terhadap kejadian stunting. Meskipun tidak ada perbedaan yang signifikan pada usia ibu dan umur kehamilan, namun pada kedua variabel ini ibu dengan usia kurang dari 20 tahun dan umur kehamilan kurang dari sama dengan 37 minggu ada kecenderungan menjadi faktor risiko, jumlah usia ibu kurang dari 20 tahun lebih banyak pada kelompok kasus dibandingkan dengan kelompok kontrol, begitu pula dengan umur kehamilan, sedangkan jarak kehamilan bukan merupakan faktor risiko terhadap kejadian stunting pada balita di Kelurahan Mulyasari.

Hasil penelitian menunjukkan bahwa balita stunting yang ibunya memiliki usia yang berisiko yaitu usia kurang dari 20 tahun tidak serta signifkan mempunyai hubungan terhadap kejadian stunting, akan tetapi usia ibu yang berisiko kurang dari 20 tahun memberikan peluang sebanyak 2,082 kali terhadap kejadian stunting pada balita. Usia ibu lebih berperan sebagai faktor psikologis terhadap kondisi seorang ibu dalam menerima kehamilannya, sehingga akan berpengaruh terhadap pola pengasuhan terhadap anak. Faktor fisiologis usia ibu berpengaruh terhadap pertumbuhan janin, namun apabila terdapat asupan makanan yang seimbang yang mampu dicerna tehadap kondisi fisiologis seorang ibu akan memberikan dampak yang positif ${ }^{9}$.

Selanjutnya status karakteristik dari ibu yang dapat kita lihat yaitu dari faktor usia kehamilan preterm (<37 minggu) dan aterm (> 37 minggu) berpeluang walaupun tidak signifikan terdapat hubungan dengan kejadian stunting, akan tetapi memberikan 
konstribusi sebesar 1,567 kali. Hasil ini tidak sejalan dengan penelitian di Kecamatan Pati Kabupaten Pati tentang faktor risiko kejadian stunting pada anak usia 12-36 bulan $(p=0,025, O R=10,67)$. Usia Kehamilan yang dikategorikan cukup bulan ( $\geq 37$ minggu) dan prematur $(<37 \text { minggu })^{10}$. Hasil penelitian Chandra tahun 2011 yang menunjukkan faktor risiko stunting pada anak 1-2 tahun adalah jarak kelahiran $<23$ bulan $(p=0,024$; $\mathrm{OR}=11,65)^{9}$, dengan demikian karakteristik usia ibu tidak secara signifikan memberikan dampak terhadap kejadian stunting pada balita. Usia kandungan kurang dari 37 minggu akan mengalami kemungkinan 11.40 kali atau 91\% untuk melahirkan BBLR daripada kelompok usia kandungan lebih dari atau sama dengan 37 minggu. Bayi yang lahir dengan keadaan berat badan lahir rendah sangat berisiko tinggi terhadap morbiditas, kematian, penyakit infeksi, kekurangan berat badan dan stunting diawal periode neonatal sampai masa kanak-kanak. Bayi dengan berat lahir rendah ini dapat dikaitkan dengan gangguan fungsi kekebalan tubuh, perkembangan kognitif yang buruk, dan berisiko terjadinya diare akut atau pneumonia $^{11}$.

Hal berbeda ditunjukkan pada variabel tinggi badan ibu merupakan faktor risiko terhadap kejadian stunting, ditunjukkan dengan hasil analisis adanya perbedaan yang signifikan $(p<0,05)$ antara kasus, yaitu balita stunting dengan non-stunting. Hasil penelitian menunjukkan bahwa ibu yang pendek $(<145$ $\mathrm{cm}$ ) mempunyai nilai COR (Crude Odds Ratio) sebesar 5,712. Artinya, bahwa peluang ibu yang pendek untuk menjadikan balita stunting sebesar 5,712 kali dibandingkan dengan ibu yang tinggi badannya lebih dari $145 \mathrm{~cm}$.

lbu dengan tinggi badan pendek lebih berpeluang untuk melahirkan anak yang pendek pula. Penelitian di Mesir menunjukkan bahwa anak yang lahir dari ibu dengan tinggi badan kurang dari $150 \mathrm{~cm}$ lebih berisiko untuk tumbuh stunting ${ }^{12}$. Hasil ini sejalan dengan penelitian pada tahun 2013 pada 1.239 balita usia 24 - 59 bulan di Provinsi Aceh, Sumatera Utara, Sumatera Selatan, dan Lampung Sumatera yang menunjukkan faktor risiko stunting pada balita $(p<0.05)$ yaitu tinggi badan ibu $(\mathrm{OR}=1.36)^{7}$.
Pada penelitian ini tidak diteliti faktorfaktor yang mempengaruhi tinggi badan lbu, sehingga tidak dapat membedakan apakah tinggi badan orang tua saat ini merupakan pengaruh genetik atau karena pengaruh patologis maupun malnutrisi. Tinggi badan merupakan salah satu bentuk dari ekspresi genetik, dan merupakan faktor yang diturunkan kepada anak serta berkaitan dengan kejadian stunting. Anak dengan orang tua yang pendek, baik salah satu maupun keduanya, lebih berisiko untuk tumbuh pendek dibanding anak dengan orang tua yang tinggi badannya normal. Pada orang tua pendek memiliki gen dalam kromosom yang membawa sifat pendek, sehingga memungkingkan diturunkan kepada anaknya, kecuali jika sifat pendek orang tua disebabkan karena masalah gizi maupun patologis $^{13}$. Tinggi badan merupakan antropometri yang mengindikasikan masalah gizi yang sifatnya kronis sebagai akibat dari pengaruh defisiensi zat gizi yang berlangsung relatif lama ${ }^{14}$.

Hasil penelitian ini memiliki keterbatasan karena hanya melihat dari karaktersitik ibu atau maternal faktor saja, diantara multifaktor lainnya yang dapat mempengaruhi terjadinya stunting, seperti: asupan, pola makan, pola asuh, kondisi ekonomi, panjang badan lahir, pendidikan orang tua, pekerjaan orang tua, pendapatan keluarga, jumlah anggota dan lain sebagainya. Hasil penelitian observasional dengan desain case-control pada balita usia 2-3 tahun di wilayah Kecamatan Semarang Timur, pada 36 subjek pada tiap kelompoknya menunjukkan faktor risiko stunting adalah status ekonomi keluarga yang rendah $(P=0,032 ; O R=4,13)$, Status ekonomi keluarga yang rendah merupakan faktor risiko yang bermakna terhadap kejadian stunting pada balita usia 23 tahun. Status ekonomi keluarga yang rendah lebih berisiko 4,13 kali mengalami anak stunting. Faktor asupan dan penyakit memegang peranan yang menentukan apakah anak yang lahir dengan panjang badan lahir rendah akan tetap stunting selama masa hidupnya atau berhasil mencapai catch-up grow yang maksimal ${ }^{15}$. 


\section{SIMPULAN DAN SARAN}

Karakteristik tinggi badan ibu merupakan faktor risiko terjadinya stunting pada balita usia 0-59 bulan. Tinggi badan ibu $<145 \mathrm{~cm}$ berisiko terjadinya stunting pada balita sebesar 5,712 dibandingkan dengan ibu dengan tinggi badan $\geq 145 \mathrm{~cm}$. Karena tinggi badan merupakan bagian dari faktor maternal yang sudah tidak mungkin dirubah pada usia tersebut maka disarankan sebaiknya ibu yang memiliki tinggi badan kurang melakukan upaya pencegahan peningkatan faktor lainnya untuk terjadinya stunting.

\section{DAFTAR PUSTAKA}

(1) Kementerian Kesehatan RI (Badan Penelitian dan Pengembangan Kesehatan). Riset Kesehatan Dasar (Riskesdas 2013). Jakarta; 2013

(2) Puskesmas Tamansari. BPB Februari 2015 dan 2016. Dinas Kesehatan Kota Tasikmalaya; 2016

(3) Kurniasih, D., H. Hilmansyah, M. P. Astuti, dan S. Imam. Sehat \& BugarBerkat Gizi Seimbang. Kompas Gramedia. Jakarta; 2010

(4) UNICEF Indonesia. Ringkasan Kajian Kesehatan Ibu dan Anak. 2012. [Cited 30 December2017]. from:www.unicef.or.id

(5) Rahayu, A. dan L. Khairiyati. Risiko Pendidikan lbu Terhadap kejadian Stunting Pada Anak 6-23 Bulan. Penel Gizi Makan. 2014; 37 (2):129-136

(6) Win, K. M., M. V. der Putten, N. Vajanapoom, K. Amnatsatsue. and Thammas. Early Pregnancy and Maternal Malnutrition as Precursors of Stunting in Children under Two Years of Age among Bhutanese Refugees, in Nepal Maternal Precursors in Stunting of Children. International Journal of Science and Technology. 2013;18 (1)

(7) Oktarina, Z. Dan T. Sudiarti. Faktor Risiko Stunting Pada Balita (24-59 bulan) di
Sumatera. Jurnal Gizi dan Pangan. 2013; $8(3): 175-180$

(8) Lestari, W. A. Margawati, M. Zen Rahfiludin. Faktor Risiko Stunting pada Anak Umur 6-24 bulan di Kecamatan Penanggalan Kota Subulussalam Provinsi Aceh. Jurnal Gizi Indonesia. 2014; 3 (1): 126-134

(9) Candra, A. Hubungan Underlying Factors Dengan 11 Kejadian Stunting Pada Anak Usia 1 - 2. 2010. [Cited 28 Mei 2015]. Available from: http://www.ejournal.undip.ac.id

(10)Anugraheni, H. S. Faktor Risiko Kejadian Stunting pada Anak Usia 12-36 Bulan di Kecamatan Pati, Kabupaten Pati [skripsi]. Semarang: Fakultas Kedokteran Universitas Diponegoro; 2012

(11)Fitri Berat Lahir Sebagai Faktor Dominan Terjadinya Stunting Pada Balita (12-59 bulan) di Sumatera (Analisis Data Riskesdas 2010). [skripsi] Jakarta: Fakultas Kesehatan Masyarakat Universitas Indonesia; 2012

(12)Zottarelli LK, Sunil TS, Rajaram S. Influence of Parental and Socioeconomics Factors on Stunting in Children Under 5 Years in Egypt. Eastern Mediterranean Health Journal, 2007 [Cited 28 Mei 2015]. Available from: http://www.emro.who.int/emhj/1306

(13)Amigo $H$, Buston $P$, Radrigan ME. Is there a relationship between parent's short height and their children's? Social interclass epidemiologic study. Rev Med Chil. $1997 ; 125(8)$

(14)Supariasa IDN, Bachyar B, lbnu F. Penilaian Status Gizi. Jakarta: EGC; 2002. pp 18-188

(15)Kusuma, K. Eka. Faktor Risiko Kejadian Stunting pada Anak Usia 2-3 Tahun (Studi di Kecamatan Semarang Timur). Journal of Nutrition College. 2013; 2 (4): 523-530 